\title{
Incidence and Distribution of Iris yellow spot virus on Onion in Serbia
}

\author{
Aleksandra Bulajić and Ivana Djekić, Institute of Plant Protection, Department of Phytopathology, University of \\ Belgrade-Faculty of Agriculture, Nemanjina 6, 11080 Belgrade, Serbia; Jelena Jović and Slobodan Krnjajić, De- \\ partment of Plant Pests, Institute for Plant Protection and Environment, Banatska 33, 11080 Belgrade, Serbia; and \\ Ana Vučurović and Branka Krstić, Institute of Plant Protection, Department of Phytopathology, University of Bel- \\ grade-Faculty of Agriculture, Nemanjina 6, 11080 Belgrade, Serbia
}

\begin{abstract}
Bulajić, A., Djekić, I., Jović, J., Krnjajić, S., Vučurović, A., and Krstić, B. 2009. Incidence and distribution of Iris yellow spot virus on onion in Serbia. Plant Dis. 93:976-982.

In a survey to determine the presence and distribution of Iris yellow spot virus (IYSV) in greenhouse ornamentals and onion field crops in 14 districts of Serbia as well as on imported ornamental plants, 1,574 samples were collected and analyzed by double-antibody sandwich enzyme-linked immunosorbent assay (DAS-ELISA). IYSV was not detected in nearly 1,200 plant samples collected from 39 genera of ornamentals grown in greenhouses in Serbia or imported from other countries during 2005 to 2007. The virus was detected in samples from an onion seed crop in the Sirig locality (South Bačka District) that showed symptoms resembling those caused by IYSV and in samples without IYSV-like symptoms from an onion bulb crop in the Obrenovac locality (City of Belgrade District). Mechanical transmission of IYSV isolates was difficult, and only the isolate 605-SRB could infect four plant species, but not in all replications. No virus transmission could be demonstrated in 5,000 tested seeds originating from IYSV-infected onion crops. For further confirmation of IYSV, the nucleotide sequence of its nucleocapsid (NC) gene was obtained by reverse transcription-polymerase chain reaction (RT-PCR) in symptomatic onion samples as well as in symptomless leaves of Nicotiana benthamiana. Four previously developed primers were tested to determine their suitability for routine detection of Serbian IYSV isolates. Phylogenetic analysis showed clustering of isolates 605-SRB and 622-SRB from the onion seed crop and isolate 283-SRB from the onion bulb crop into two distant clades. The analysis indicated that Serbian isolates of IYSV do not share a recent common ancestor and that they represent two distinct lineages of IYSV in Serbia. Considering that onion is one of the most important and traditionally grown vegetable crops in Serbia, IYSV represents a potentially devastating pathogen in this country.
\end{abstract}

In the last few decades, the genus Tospovirus within the family Bunyaviridae has become one of the most studied plant virus genera. Iris yellow spot virus (IYSV) is one of the several members of the Tospovirus genus (25). IYSV is considered an emerging virus whose world presence and distribution have recently dramatically increased $(17,36,38)$.

IYSV is an economically important viral pathogen of onion (Allium cepa), but the infection of other cultivated and wild $A l$ lium species, several ornamental species, and a certain number of weeds has also been reported $(17,36,37,46)$. IYSV is not reported to be seedborne and seedtransmitted in onion $(27,31)$, but the question whether it can be transmitted through

Corresponding author: B. Krstić

E-mail: branka.krstic@agrif.bg.ac.rs

Accepted for publication 22 May 2009.

doi:10.1094/PDIS-93-10-0976

(C) 2009 The American Phytopathological Society seeds has often been raised because seed transmission could be affected by numerous factors.

Scape blight of onion with unusual symptomatology was observed for the first time in 1989 in Idaho and Oregon, USA, but a tospovirus associated with the disease was reported only in 1993 (20). Almost at the same time, an unknown tospovirus causing disease on onion was found in Brazil (42) and on iris and leek in the Netherlands $(2,14)$. In 1998, the tospovirus isolated from iris in the Netherlands was identified and the name Iris yellow spot virus was proposed (12). Further characterization of onion and iris isolates of the tospoviruses identified in Brazil, the United States, and the Netherlands proved that it was the same virus, IYSV $(32,41)$. The virus was reported soon afterward in Israel $(18,19)$. Since then, IYSV has been reported in several parts of the world and in various states of the United States (17). Recently, first reports on finding of IYSV have come from Canada (21) and New Zealand (52). IYSV has caused considerable losses in the United States, especially in the western regions of onion production, where since 2000 the virus has spread and its incidence has been increasing rapidly (36).

In the EPPO region, this newly characterized tospovirus gained significance in 1999, when it was included in the EPPO Alert List (3), because it could pose a risk for the cultivation of onion and other host plants. The present geographical distribution of IYSV is still under investigation, and in most cases the virus records were incidental findings. Until now, survey for the virus has been initiated only by several countries, and in almost all of them IYSV has been detected only sporadically and in restricted areas. In addition to the Netherlands and Israel, IYSV has been recorded in Slovenia (29), Italy $(7,13)$, Poland (8), Spain $(10,11)$, France $(22,23)$, Germany $(5,28)$, the UK (33), and Serbia (9).

Despite the fact that IYSV has increased its geographical distribution in the EPPO region and that further spread of IYSV would be expected, especially in fieldgrown onion, information on the present distribution and actual incidence level is uncertain and assessment of its economic impact is still missing. The current situation in the European countries concerning IYSV highlights the need for extensive research to gather more information to prevent its further spread in Europe.

The objectives of this study were to (i) gain an insight into the occurrence and distribution of IYSV in greenhouse-grown ornamentals and onion crops in Serbia, (ii) determine possible IYSV presence in suspected host plants of imported ornamentals, (iii) investigate possible seed transmission of IYSV in onion, and (iv) determine the genetic relationship of Serbian IYSV isolates with those from other parts of the world.

\section{MATERIALS AND METHODS}

Survey and sample collection. An intensive survey was conducted during 2005 to 2007 to determine the occurrence and distribution of IYSV on ornamentals grown in 14 districts of Serbia and onion grown in nine of them (Fig. 1). In 2005, during an initial survey, 453 samples of ornamentals were collected after visual 
inspection of approximately $1,170,000$ plants produced in 59 greenhouses from 24 different localities. Collected ornamentals belonged to 35 genera: Abutilon, Alstroemeria, Amaryllis, Begonia, Belis, Calla, Celosia, Chrysanthemum, Dahlia, Datura, Dianthus, Diascia, Dicentra, Gladiolus, Hibiscus, Impatiens, Iris, Lobelia, Lysimachia, Mimulus, Pelargonium, Peperonia, Petunia, Phlox, Primula, Ranunculus, Rosa, Saintpaulia, Salvia, Sinningia, Vanila, Verbena, Viola, Zamioculcas, and Zinnia. In addition, during 2005, approximately 18,700 imported ornamental plants were visually inspected, and 516 samples of Iris, Alstroemeria, Eustoma, and Chrysanthemum were collected and tested for IYSV presence. In 2006, 215 ornamental samples were collected from approximately 820,000 inspected plants grown in 39 greenhouses at 16 localities. Samples included plants from 14 genera: Begonia, Chrysanthemum, Cyclamen, Dianthus, Impatiens, Iris, Lilium, Pelargonium, Petunia, Primula, Sinningia, Tagetes, and Vinca.

During a 3-year period of visual inspection of 75 onion fields to record symptoms resembling those of IYSV, a total of 390 samples were collected. Onion production fields were diverse in size and production scale. Some fields were less than $5,000 \mathrm{~m}^{2}$, while others were substantially larger, up to 20 ha. In 2005, a total of 52 samples of onion plants were collected from 20 bulb and 11 seed crops in the vicinity of 31 greenhouses for ornamental plant production. During 2006, a total of 149 samples of onion were collected from eight bulb and five seed crops, each from a different locality, and in 2007, 189 onion leaf samples were collected from 13 bulb and 18 seed onion crops from 16 localities.

Samples of ornamentals comprised of leaves from different parts of each plant exhibited various symptom types suggestive of tospovirus infection, such as yellow or necrotic spots and rings on leaves and tip necrosis. Symptomless onion leaf and scape samples were collected together with those showing symptoms of elongated, oval chlorotic or necrotic lesions. Both fresh and frozen $\left(-80^{\circ} \mathrm{C}\right)$ samples were tested for IYSV presence by enzymelinked immunosorbent assay (ELISA).

Serological testing. Samples were tested for the presence of IYSV utilizing a double-antibody sandwich (DAS)-ELISA kit (Loewe Biochemica, Sauerlach, Germany), and the ELISA procedure was performed according to manufacturer's instructions. Plant tissue samples were extracted in extraction buffer at a rate of $1: 10$ (wt/vol). After incubation with $p$ nitrophenyl phosphate (Sigma-Aldrich, St. Louis, MO) at $23^{\circ} \mathrm{C}$ for 1 to $2 \mathrm{~h}$ in dark, absorbance at $405 \mathrm{~nm}$ was measured with an ELISA microplate reader (DASsrl, Italy). Samples were considered positive if the absorbance value was equal to or higher than two times the absorbance of the negative control. Commercial positive controls for IYSV (Loewe) and negative controls (extract from healthy onion leaf tissue, commercially available negative control from Loewe and extraction buffer) were included in each ELISA.

Bioassay. Nicotiana benthamiana, $N$. tabacum cvs. Samsun and Prilep, N. rustica, N. glutinosa, Chenopodium quinoa, C. amaranticolor, Datura stramonium, Petunia $\times$ hybrida, Physalis floridana, and Gomphrena globosa were mechanically inoculated with infected onion sap, using chilled $0.05 \mathrm{M}$ phosphate buffer ( $\mathrm{pH} 7$ ) containing $1 \mathrm{mM}$ Na-EDTA, $5 \mathrm{mM}$ NaDIECA, and $5 \mathrm{mM}$ Na-thioglycolate (44). Mechanical transmission to test plants was performed using two ELISA-positive samples, 605-SRB from onion bulb and 283SRB from onion seed crops, originating from the localities of Sirig and Obrenovac, respectively. A total of 10 plants of each experimental species were inoculated, and the bioassay was repeated three times. Plants were kept in an insect-proof greenhouse at a temperature of 22 to $25^{\circ} \mathrm{C}$ and were inspected regularly for symptom development. Three weeks after inoculation, both symptomatic and asymptomatic plants were assayed by DAS-ELISA to confirm IYSV presence and to detect symptomless infections. Only the ELISApositive symptomless leaves of $N$. benthamiana were further tested using reverse transcription-polymerase chain reaction (RT-PCR).

Seed transmission. Seed transmission was investigated using mature seeds from naturally infected onion plants showing severe and distinct symptoms. Infection of source seed plants with IYSV was confirmed by ELISA testing their symptomatic scapes. Seeds were sown in plastic trays with a sterilized mixture of soil and

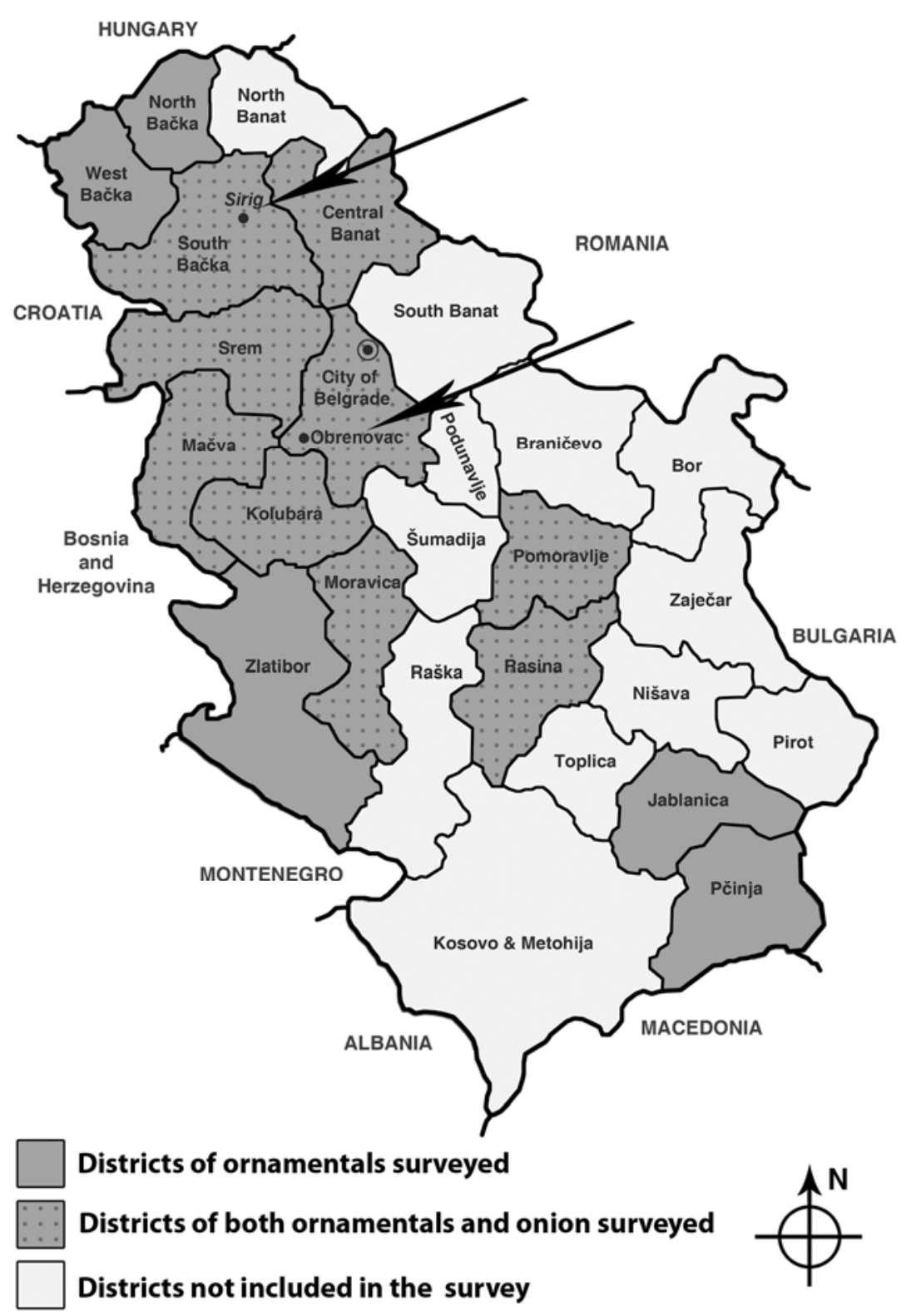

Fig. 1. Map of Serbia showing districts surveyed for Iris yellow spot virus (IYSV) presence. Arrows inidicate two localities where IYSV was found. 
sand in an insect-proof greenhouse, and symptoms on seedlings were monitored on a weekly basis. The IYSV presence was determined in 10-week-old seedlings using ELISA. Leaf samples of a total of 5,000 seedlings were assayed in groups of five. Seedlings grown from seeds collected from healthy plants were used as a control.

RT-PCR detection and sequence analysis. Total RNA was extracted from freeze-dried symptomatic onion leaves and scapes and fresh symptomless leaves of $N$. benthamiana using the RNeasy Plant Mini Kit (Qiagen, Hilden, Germany) following the manufacturer's instructions. Tissue sample from healthy onion leaf was used as a negative control in RNA extraction and RT-PCR amplification. Specific nucleotide sequence of IYSV nucleocapsid (NC) gene was detected using RT-PCR with several previously developed primers (Table 1).

RT-PCR was carried out with the OneStep RT PCR kit (Qiagen, Hilden, Germany) according to the manufacturer's instructions. The RT-PCR reaction mixture included $400 \mu \mathrm{M}$ each of the four dNTPs, $0.6 \mu \mathrm{M}$ each primer, and $1 \mu \mathrm{l}$ extracted
RNA in a final volume of $25 \mu \mathrm{l}$. Cycling conditions were as follows: 35 cycles in a thermal cycler (Biometra, T-1 Thermocycler) applying $30 \mathrm{~min}$ at $50^{\circ} \mathrm{C}$ for reverse transcription, $30 \mathrm{~s}$ (15 min for the first cycle) at $94^{\circ} \mathrm{C}$ for denaturation, conditions for annealing depending on the used primers (Table 1), and $30 \mathrm{~s} \mathrm{(10} \mathrm{min} \mathrm{for} \mathrm{the} \mathrm{last}$ cycle) at $72^{\circ} \mathrm{C}$ for primer extension. Amplified products were analyzed by $1 \%$ agarose gel electrophoresis, stained with ethidium bromide, and visualized under a UV transilluminator.

The amplification products of predicted size, obtained using IYSV917L/56U primers, derived from the isolates 605-SRB and 622-SRB were sequenced directly after the purification with QIAquick PCR Purification Kit (Qiagen). Due to some nonspecific amplification, the fragment of expected size of the isolate 283-SRB was excised from the gel and subsequently purified using QIAquick Gel Extraction Kit (Qiagen) before sequencing. Sequencing was performed on an automated equipment (BMR Genomics, Padova, Italy) using both primers. The nucleotide sequences of the amplification products were deposited

Table 1. Primers used for Iris yellow spot virus detection

\begin{tabular}{|c|c|c|c|c|}
\hline Primer & Sequence $\left(5^{\prime}\right.$ to $\left.3^{\prime}\right)$ & $\begin{array}{l}\text { Annealing } \\
\text { temp./time }\end{array}$ & $\begin{array}{c}\text { Amplicon } \\
\text { size (bp) }\end{array}$ & Ref. \\
\hline IYSV917L & TAAAACTTAACTAACACAAA & $40^{\circ} \mathrm{C} / 1 \mathrm{~min}$ & 896 & 43 \\
\hline IYSV56U & TCCTAAGTATTCACCAT & & & \\
\hline IYSV-Pappu $1^{\mathrm{a}}$ & TAAAACAAACATTCAAACAA & $42^{\circ} \mathrm{C} / 2 \min$ & 1,200 & 36 \\
\hline IYSV-Pappu2 & СТСТТАААСАСАТТТААСАAGCAC & & & \\
\hline IYSV-459 & ACCAGAGGAAGCCCGCAG & $54^{\circ} \mathrm{C} / 30 \mathrm{~s}$ & 459 & 51 \\
\hline TOS-R15 & GGGAGAGCAATYGWGKYR & & & \\
\hline IYSV-F & TCAGAAATCGAGAAACTT & $50^{\circ} \mathrm{C} / 1 \mathrm{~min}$ & 700 & 16 \\
\hline IYSV-R & TAATTATATCTATCTTTCTTGG & & & \\
\hline
\end{tabular}

${ }^{a}$ Reference sources included no primer name, and a suitable designation was allocated.

Table 2. Isolates with the nucleocapsid gene sequences of Iris yellow spot virus used

\begin{tabular}{lllll}
\hline Isolate & Geographical origin & Host & Accession no. & Ref. \\
\hline SgA & Saga, Japan & Lisianthus & AB180921 & 15 \\
SgOniD1 & Saga, Japan & Onion & AB180919 & Unpub. data \\
T3 & Shizuoka, Japan & Lisianthus & AB121026 & 15 \\
Br10 & Brazil & Onion & AF067070 & 41 \\
Isra1 $^{\text {a }}$ & Israel & Lisianthus & AF271219 & 26 \\
NL $^{\text {a }}$ & The Netherlands & Iris & AF001387 & 12 \\
UK & Suffolk, UK & Lisianthus & AM900393 & 33 \\
Slov1 & Slovenia & Leek & AY377428 & Unpub. data \\
IYSV-ALB & Spain & Onion & EF419888 & 11 \\
IYSV-VAL & Spain & Leek & EF427447 & 12 \\
Cip3 & Northern Italy & Onion & FJ185142 & Unpub. data \\
Chile & Chile & Onion & DQ150107 & 45 \\
WAPasco & Pasco,Wash.,USA & Onion & DQ233469 & 36 \\
Shallot & Grant Co.,Wash.,USA & Shallot & DQ233471 & 36 \\
IDNampa & Nampa, Idaho, USA & Onion & DQ233472 & 36 \\
Ica & Ica, Peru & Onion & DQ838584 & 35 \\
Supe1 & Supe, Peru & Onion & DQ838585 & 35 \\
Guat2 & Guatemala & Onion & DQ838590 & 35 \\
Georgia2 & Georgia & Onion & DQ838592 & 35 \\
Georgia3 & Georgia & Onion & DQ838593 & 35 \\
New Zealand & New Zealand & Onion & EU477515 & 52 \\
605-SRB & Sirig, Serbia & Onion & EU586203 & 9 \\
622-SRB & Sirig, Serbia & Onion & EU750697 & This study \\
283-SRB & Obrenovac, Serbia & Onion & EU727180 & This study \\
\hline
\end{tabular}

a Where no isolate code was supplied in the GenBank submission, a suitable isolate designation was allocated.

in GenBank and compared with those of previously reported IYSV isolates (Table 2), which were retrieved online from the National Center of Biotechnology Information (NCBI) (http://www.ncbi.nlm.nih. gov/BLAST/). Multiple sequence alignment was done using ClustalW (50). Selected sequences including sequences of all available European IYSV isolates were trimmed to $741 \mathrm{bp}$, the length of the shortest fragment. Calculation of the divergence in NC-gene nucleotide sequences of selected isolates and phylogenetic analysis were conducted using the MEGA4 software (49). Phylogenetic trees were constructed using the maximum parsimony method and bootstrap analysis with 1,000 replicates.

\section{RESULTS}

Virus detection and symptomatology. IYSV was not detected by ELISA in any of the 668 ornamental samples collected during 2005 and 2006, nor was it detected in 516 samples of ornamentals imported in 2005. In onion crops, symptoms resembling those of IYSV were observed in only one location. In July 2007, onion plants (cv. Stuttgarter) with chlorotic or necrotic, spindle and diamond-shaped lesions on leaves and especially on scapes (Fig. 2) were observed in an onion seed production field in the Sirig locality (South Bačka District). Affected plants were spread across the field with very high disease incidence, estimated at $80 \%$. Disease occurrence was associated with a high population of Thrips tabaci. IYSV was detected by ELISA in 26 out of 34 symptomatic onion samples. Another outbreak was recorded in June 2007 in the Obrenovac locality (City of Belgrade District). Only two infected onion plants (cv. unknown) with chlorotic spots and streaks were found in an onion bulb crop with relatively low population of Thrips tabaci. IYSV was detected serologically in both samples.

Host range. Mechanical transmission of the virus from symptomatic onion samples was performed with variable success, depending on the virus isolate. The isolate from a symptomatic onion bulb sample (283-SRB) could not be mechanically transmitted to any inoculated plant. Isolate 605-SRB from an onion seed sample infected four experimental host species, but mechanical transmission occurred rarely and symptoms on test plants did not appear in all replications. C. quinoa (5 infected/30 inoculated) developed discrete chlorotic spots on inoculated leaves, and N. tabacum cvs. Samsun (4/30) and Prilep (2/30) developed mild mosaic within 5 and 14 days after inoculation, respectively. All inoculated test plants were assayed for further confirmation of IYSV by ELISA. Several symptomless $N$. benthamiana (7/30) plants were ELISA-positive, and IYSV infection was additionally confirmed by RT-PCR. No local or systemic symptoms occurred 
on $N$. rustica, N. glutinosa, C. amaranticolor, D. stramonium, Petunia $\times$ hybrida, Physalis floridana, and G. globosa after inoculation with the isolate 605-SRB, and the virus presence could not be detected by ELISA.

Seed transmission. No symptoms were observed on onion seedlings grown from seeds harvested from IYSV-infected plants, up to 10 weeks after seed emergence. All leaf samples (groups of five) from these seedlings were negative when tested by ELISA. These results indicate that the virus could not be transmitted through seeds from infected onion plants to seedlings.

Molecular detection and characterization. RT-PCR using different specific primer pairs detected IYSV presence in symptomatic onion samples, as well as in ELISA-positive symptomless inoculated leaves of $N$. benthamiana.

The suitability of four primer pairs for detection of Serbian IYSV isolates in onestep RT-PCR was also assessed. In no reactions was amplification recorded from the healthy onion control. Primers showed different specificity and ability to detect IYSV isolates from Serbia (Fig. 3). None of the Serbian isolates could be amplified with IYSV-F/R primers. Primers IYSVPappu1/2 amplified all isolates originating from the Sirig locality generating one clear band, but no isolate originating from the Obrenovac locality was amplified. Primers IYSV917L/56U and IYSV-459/TOS-R15, successfully detected IYSV in all tested samples and amplified cDNA fragments of predicted size. Although these two primer pairs were able to detect the virus in all tested samples regardless of their origin, they differed slightly. Some nonspecific amplification was detected using IYSV917L/ $56 \mathrm{U}$ primers with two isolates from the Obrenovac locality, while IYSV-459/TOSR15 primers amplified one clear band of $459 \mathrm{bp}$.

The sequences of isolates 605-SRB (GenBank Acc. No. EU586203), 622-SRB (EU750697), and 283-SRB (EU727180) proved to be identical at the nucleotide level of 86.5 to $97.8 \%$ with those from other parts of the world. Pairwise nucleotide sequence comparison revealed $99.2 \%$ identity between isolates 605-SRB and 622-SRB. The sequences of these two isolates differed from each other only at six nucleotide positions, of which one was predicted to cause an amino acid substitution (99.6\% aa identity). Isolate 283-SRB differed from isolates 605 -SRB and 622SRB at 29 (96.4\% nt identity) and 27 (96.6\% nt identity) nucleotide positions; the differences were predicted to cause nine $(96.7 \%$ aa identity) and eight $(97.1 \%$ aa identity) amino acid substitutions, respectively. Nucleotide sequences of iso-
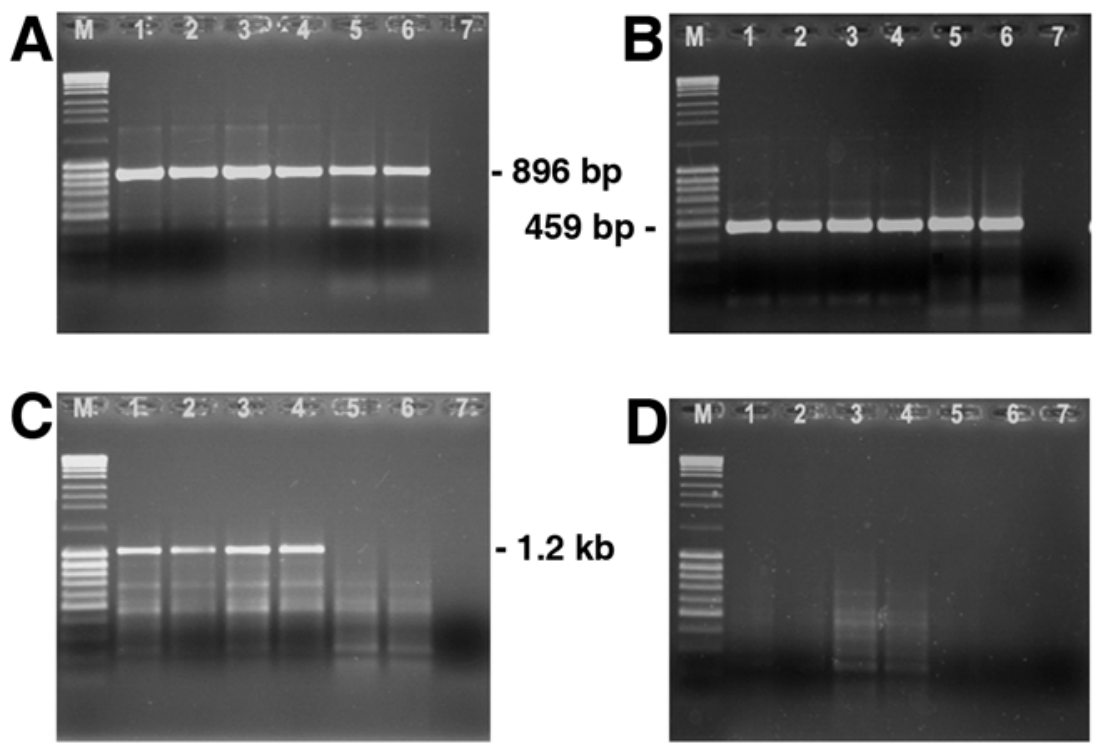

Fig. 3. Detection of nucleocapsid gene sequence of Iris yellow spot virus by reverse transcriptionpolymerase chain reaction (RT-PCR) with primers A, IYSV917/IYSV56U, B, IYSV-459/TOS-R15, C, IYSV-Pappu1/IYSV-Pappu2, and D, IYSV-F/IYSV-R primers. Lane M, MassRuler DNA ladder, Mix (Fermentas Life Sciences $\mathrm{GmbH}$, Lithuania); lanes 1 to 4, field samples originating from the Sirig locality; lanes 5 and 6, field samples originating from the Obrenovac locality; lane 7, healthy onion plant.

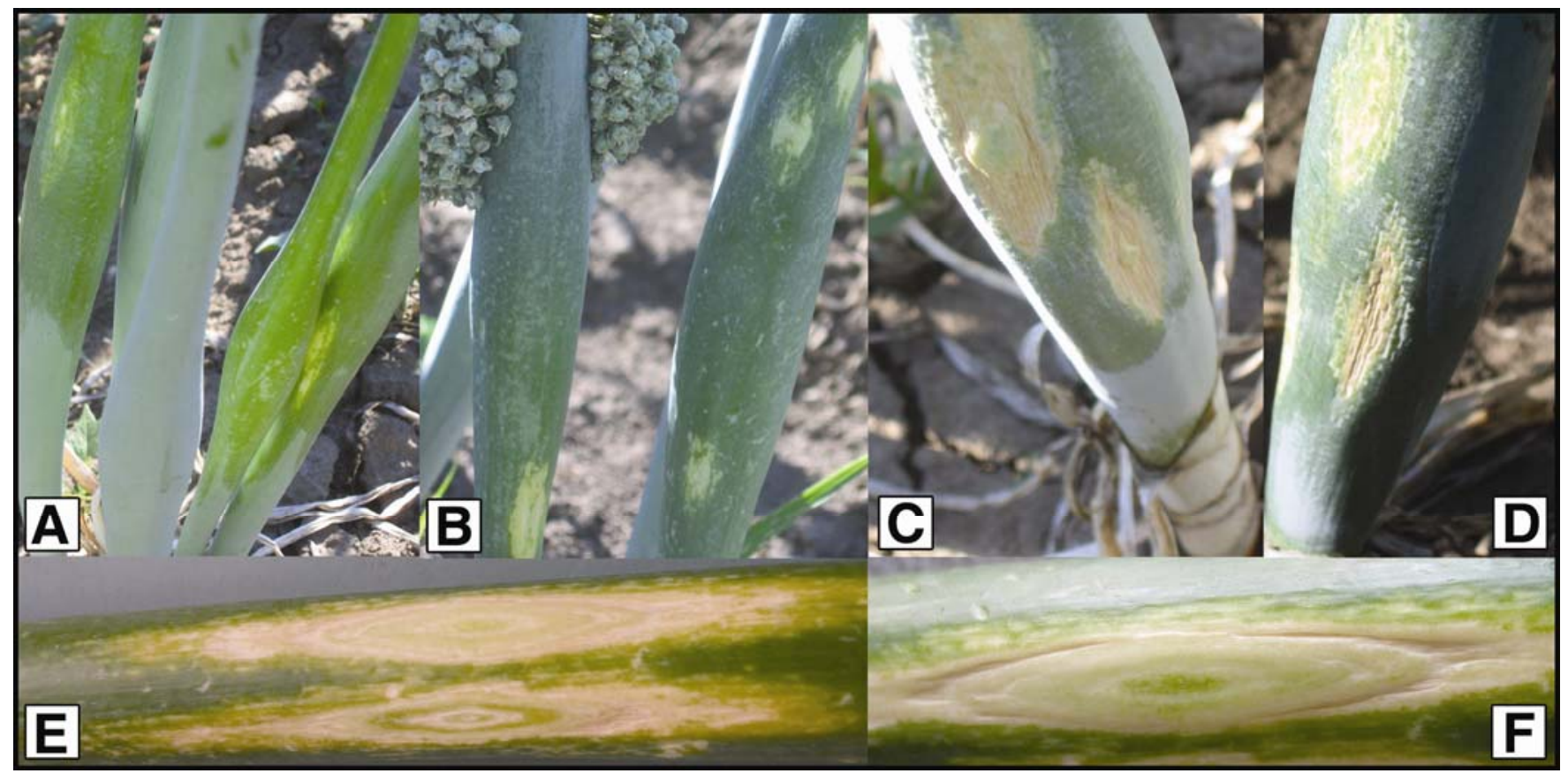

Fig. 2. Symptoms of Iris yellow spot virus infection in an onion seed crop. Characteristic symptoms on scapes include chlorotic spindle-shaped lesions with yellow centers (A and $\mathbf{B})$, necrotic lesions with yellow or tan borders with $(\mathbf{C})$ or without (D) distinct green centers, and typical diamond-shaped lesions with concentric alteration of green and straw-colored tissue $(\mathbf{E}$ and $\mathbf{F})$. 
lates 605-SRB and 622-SRB showed the highest homology with the Italian onion isolate of 97.6 and $97.8 \%$, respectively. Sequence of isolate 283-SRB had the highest homology of $99.2 \%$ with Japanese lisianthus isolate. Sequences of the three Serbian isolates were most distant (86.5 to $87.3 \%$ nt identities) from the Slovenian leek isolate.

The consensus tree was inferred from 21 most parsimonious trees (Fig. 4). Maximum parsimony analysis resulted in six distinct clades with high nucleotide homology among sequences belonging to the same clade and with high bootstrap support. Two clades consisted of single isolates, clade 1 (Slovenian isolate) and clade 4 (Brazilian isolate). Clade 2 contained isolates from the Netherlands, the UK, and Israel (96.9 to $99.7 \%$ nt identities). Clade 3 had isolates from Italy, Spain, and 605SRB and 622-SRB from Serbia (96.9 to $99.7 \%$ nt identities). Clade 5 consisted of Georgia and Peru isolates (98.4 to $99.6 \%$ nt identities), and in clade 6, isolates from the western United States, Japan, New Zealand, Guatemala, and Chile were clustered
(98.2 to $99.9 \%$ nt identities), and isolate 283-SRB from Serbia was within this clade. The phylogenetic tree also revealed a joint clustering of 283-SRB and Chile isolates in one branch, which could be considered as one subclade within clade 6 .

\section{DISCUSSION}

There are still many uncertainties about IYSV epidemiology, although it is well known that the virus host range includes several edible and wild Allium species as well as some ornamental plants (17). In the EPPO region, among ornamentals, natural infection with IYSV was recorded on Iris hollandica (12,14), Hippeastrum hybridum (19), Eustoma grandiflorum and E. russellianum (4,26,33), and Alstroemeria (4) and Chrysanthemum sp. (8), while Impatiens sultani (15), I. walleriana (14), and Petunia $\times$ hybrida (15) were artificially infected. All these ornamental hosts are at risk along with Allium species. On the other hand, a systemically infected host, whether it is onion or ornamental, is a potential source of infection for other hosts (26). In view of the assumption that IYSV

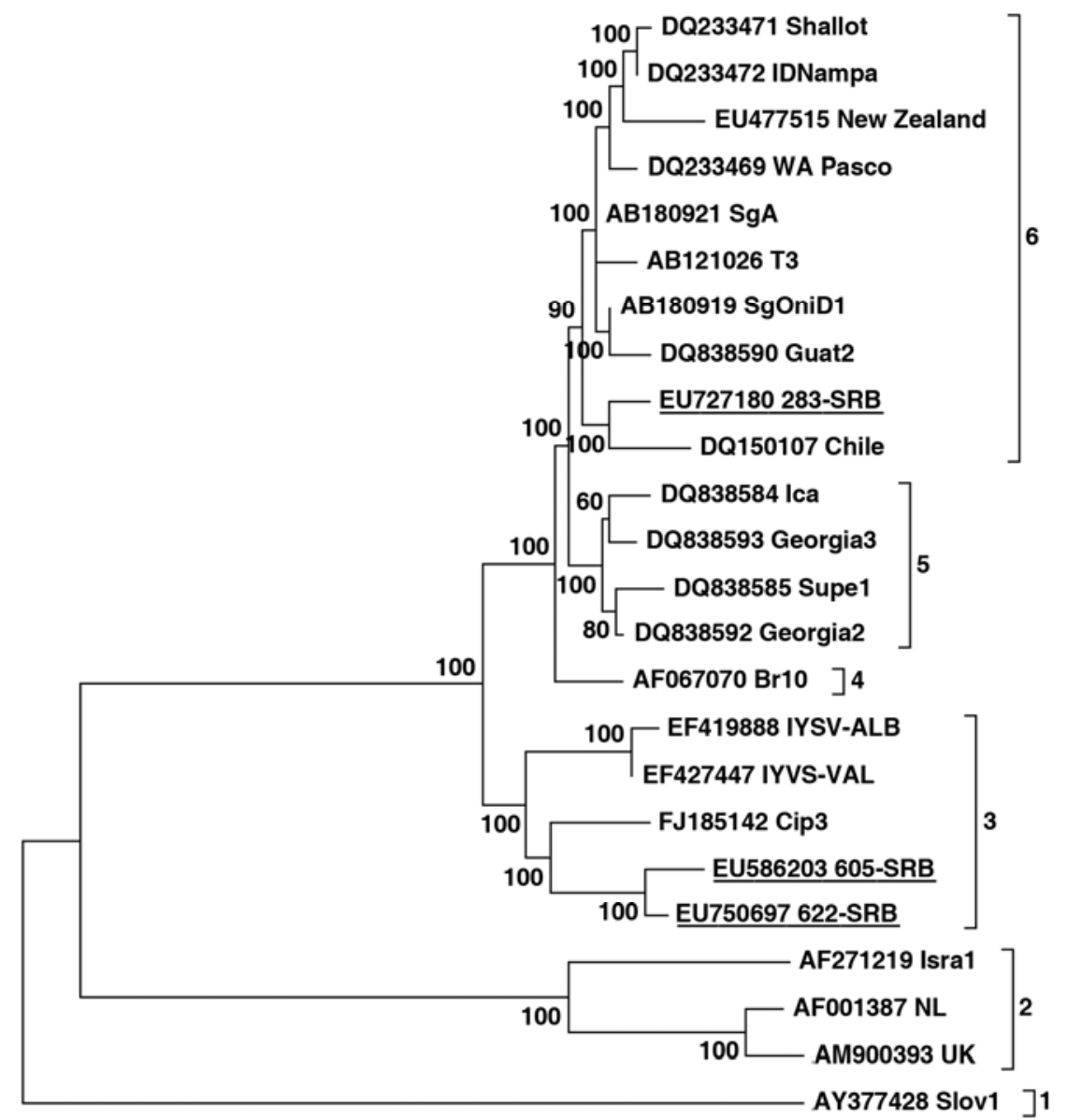

\section{0}

Fig. 4. Maximum parsimony tree based on nucleotide sequences of partial nucleocapsid gene of 24 isolates of Iris yellow spot virus (IYSV) using Slovenian IYSV isolate as the outgroup sequence. Phylogram was generated with MEGA 4 using default parameters. Percentages of parsimonious trees in which the associated taxa clustered together are shown next to the branches. Bar lengths are proportional to the number of base substitutions per site. The three Serbian isolates are underlined. is spread through international trade of ornamental propagation material, an intensive survey of greenhouse-grown ornamentals was conducted in Serbia. Testing for the presence of IYSV in numerous greenhouse-grown as well as in imported ornamentals did not reveal infection by the virus. With the exception of a previously reported outbreak of IYSV in an onion seed crop (9), the virus was found in one additional locality - in an onion bulb crop located more than $150 \mathrm{~km}$ from the previously reported locality. Besides ascertaining that the new disease of onion found in Serbia is caused by IYSV, this study extends the information provided in most recent reports about distribution of IYSV in European countries (5-7,10,22,28,33).

IYSV infection is often associated with characteristic symptoms on diseased onion plants such as straw-colored ringspots, diamond-shaped lesions, or necrotic eyelike spots $(18,39,41)$. Some of these typical symptoms of diagnostic value were observed on onion plants in the Sirig locality. In the Obrenovac locality, onion plants did not express symptoms indicative of IYSV infection, and IYSV infection could only be confirmed by laboratory testing. A similar situation was reported in the Netherlands in 2006 (6), where, in contrast to many reports from other European countries, IYSV was mainly found in symptomless onion plants or in a few plants showing mild symptoms. These findings support consideration that IYSV could be more widely spread in Europe than is currently known and that its incidence might be underestimated at present. In this case, there is a possibility that IYSV is wellestablished in Europe but presently at low levels. However, further spread and increased impact could potentially take place if the conditions for virus outbreaks develop in the future. Although symptomatology is known to be associated with many factors, various symptoms found in onion fields led us to the assumption that there may be different strains of the virus present in Serbia.

Variation in biological properties and differences in host reactions among IYSV isolates have been reported on a number of hosts $(12,26,41)$. This study confirmed that mechanical transmission of IYSV from infected onion samples is difficult. Furthermore, mechanical transmission of isolate 283-SRB was not possible. Although isolate 605-SRB infected four commonly used IYSV test plant species, transmission of the virus occurred rarely. Interestingly, this isolate caused symptomless infection of $N$. benthamiana, while most IYSV isolates caused systemic infection $(12,14,26,41)$ or local lesions (48). The failure to mechanically transmit isolate $283-\mathrm{SRB}$ to test plants did not let us compare it with isolate 605$\mathrm{SRB}$, and no correlation could be established between their phenotypes and molecular variability. 
IYSV is not considered to be seedborne or seed-transmitted in onion (27,31). Robène-Soustrade et al. (43) were not able to detect IYSV in onion seed lots but found it in fairly high percentage in 45day-old seedlings from a nursery. Also, it is well known that numerous factors affect seed transmission such as virus strain, host species and cultivar, environment during seed production, and time of infection. In view of these facts, a large number of seeds produced on IYSV-infected plants were tested. However, there is no evidence of seed transmission, which confirmed earlier findings that IYSV is not transmitted to onion seedlings from infected mother plants through the seed.

Both primer pairs IYSV-459/TOS-R15 and IYSV917L/56U were able to amplify both groups of Serbian isolates of different origin, each resulting in one distinctive band, and proved to be useful for routine molecular detection, as well as for fieldbased epidemiological studies. IYSV917L/ $56 \mathrm{U}$ primers amplified a larger product covering the entire NC-gene, and because of that they were used for further molecular characterization of the Serbian IYSV isolates. The other two primer pairs could not detect one or both IYSV isolate groups from Serbia. The absence of successful amplification with IYSV-F/R primers is due to observed differences in nucleotide sequences in both forward and reverse primer sites in both groups of Serbian isolates. IYSV-Pappu1/2 primers could not amplify isolates originating from the Obrenovac locality, also suggesting possible sequence differences at the primer site which, in this case, could not be confirmed due to the smaller size of sequences.

Sequence diversity among IYSV isolates has been reported in the United States $(1,35,36)$, as well as the lack of diversity among Australian isolates (47). The phylogenetic analysis performed in this study showed high variation between IYSV isolates originating from two distant localities in Serbia. Two isolates originating from the Sirig locality (605-SRB and 622-SRB) clustered with European isolates from Italy and Spain, but isolate 283-SRB, originating from the Obrenovac locality, fell into a different and distant clade. Similarly, it was reported that an Oregon onion isolate had significant divergence from the others originating from the western United States, and it was grouped with IYSV isolates from the Netherlands and Israel (36). The analysis also indicated that Serbian IYSV isolates do not share a recent common ancestor and that there are two distinct lineages of IYSV in Serbia. The clustering of isolates from Serbia in distinct clades 3 and 6 suggests two introductions of IYSV at different times, as was similarly reported for isolates from California (36). The high sequence divergence among European IYSV isolates, their clustering into four different clades, and the occurrence of the most divergent isolate so far from Slovenia indicate a longer association with the virus, such as was stated for Japan (47). Interestingly, clustering of one of the Serbian isolates into the clade with isolates from different parts of the world (the United States, Japan, New Zealand, and Chile) potentially indicated extensive and rapid spread of the virus throughout the world, probably due to increasing international trade. The nature and extent of the genetic diversity among IYSV isolates still remain unclear and speculative, apart from the knowledge that the genetic variation has not been associated with differences in vector specificity $(12,34)$. Pozzer et al. (41) suggested that divergence between IYSV isolates from Brazil and the Netherlands reflected an adaptation of those isolates to different environmental conditions. Smith et al. (47) reported that genetic diversity among IYSV isolates from Brazil, Japan, Israel, and Australia were not associated with either the climatic conditions or original hosts. However, clustering of IYSV isolates based on geographic origin with some exceptions was also reported (17,36). Phylogenetic analyses based on IYSV NC-gene sequences may point to introduction of the virus into a particular region or country $(26,36)$, the continent (47) or the occurrence of gene flow from one country to another (35). Sequencing and phylogenetic analyses of more isolates, especially from Europe, would provide additional information on the implications of high genetic diversity among IYSV isolates worldwide.

While IYSV has become a major constraint for the production of onion bulb and seed crops, especially in various states of the United States (40), Israel (19), and Brazil (41), the situation in Europe regarding its presence, distribution, and economic impact is still not completely understood. Despite the wide distribution of Thrips tabaci in natural vegetation and the fact that its most numerous populations in recent years were found in onion (30) and ornamental crops (24), until now outbreaks of the disease have been sporadic and limited. In European countries in which the virus is detected, its status can be described as: present, transient, incidental or isolated findings, or present without causing damage. There is no information on damage and economic impact, except that estimated incidence on onion was high in Slovenia (29) and that severely infected plants eventually died in Spain (11). However, most recent records of IYSV outbreak in several European countries such as Italy (7), Germany (5), the UK (33), and Serbia (9), and the virus occurrence in different areas of France on onion and shallot (22), as well as a new report on leek in Spain (10) could represent increasing incidence of IYSV in Europe.

Although IYSV was first recorded in Europe in 1992, and phylogenetic analysis indicated its presence in Europe, it is not clear why the virus has not been such a serious problem so far as it has been in other parts of the world. This situation might be explained by differences in onion production systems. While in Europe onion is usually produced from plant sets, in the United States it is produced from transplants (10 to 20\%) and seed (80 to $90 \%$ ). Considering the most recent reports on records in new countries, increased incidence and rapid spread in Europe, its emerging status as well as a serious threat to onion production worldwide, further investigations are needed, especially on the efficiency of the vector with respect to the European ecotypes in transmitting the virus, the presence of susceptible host plants and alternative hosts. The results from this study, together with those of first reports on the presence of IYSV in European countries, indicate that the virus has been established in Europe and that it is necessary to prevent its further spread in onion as well as in other susceptible crops.

\section{ACKNOWLEDGMENTS}

We thank Hanu R. Pappu from the Department of Plant Pathology, Washington State University, Pullman, USA for a critical review of the manuscript and helpful suggestions. This research was supported, in part, by grant 321-0009/2005-11 from the Ministry of Agriculture, Forestry and Water Management, Republic of Serbia.

\section{LITERATURE CITED}

1. Abad, J. A., Speck, J., Mohan, S. K., and Moyer, J. W. 2003. Diversity of the Iris yellow spot virus $\mathrm{N}$ gene in the USA. (Abstr.) Phytopathology 93:S1.

2. Anonymous. 1998. Iris yellow spot tospovirus in leek. Pages 118-119 in: Annual Report 1997, Diagnostic Centre. Plant Protection Service, the Netherlands.

3. Anonymous. 2000. EPPO Alert List. Iris yellow spot tospovirus. http://www.eppo.org/ QUARANTINE/Alert_List/viruses/IYSV00.htm.

4. Anonymous. 2007. Iris yellow spot virus detected on Eustoma in the Netherlands. EPPO Reporting Service 1:008.

5. Anonymous. 2008. First report of Iris yellow spot virus on onion in Germany. EPPO Reporting Service 2:033.

6. Anonymous. 2008. New findings of Iris yellow spot virus in the Netherlands in 2007. EPPO Reporting Service 3:060.

7. Anonymous. 2008. First record of Iris yellow spot virus in Italy. EPPO Reporting Service $8: 163$.

8. Balukiewics, A., and Kryczynski, S. 2005. Tospoviruses in chrysanthemum mother stock plants in Poland. Phytopathol. Pol. 37:59-67.

9. Bulajić, A., Jović, J., Krnjajić, S., Petrov, M. Djekić, I., and Krstić, B. 2008. First report of Iris yellow spot virus on onion (Allium cepa) in Serbia. Plant Dis. 92:1247.

10. Córdoba-Sellés, C., Cebrián-Mico, C., AlfaroFernández, A., Muñoz-Yerbes, M. J., and Jordá-Gutiérrez, C. 2007. First report of Iris yellow spot virus in commercial leek (Allium porrum) in Spain. Plant Dis. 91:1365.

11. Córdoba-Sellés, C., Martínez-Priego, L., Muñoz-Gómez, R., and Jordá-Gutiérrez, C. 2005. Iris yellow spot virus: A new onion disease in Spain. Plant Dis. 89:1243.

12. Cortês, I., Livieratos, I. C., Derks, A., Peters, D., and Kormelink, R. 1998. Molecular and serological characterization of iris yellow spot virus, a new and distinct Tospovirus species. 
Phytopathology 88:1276-1282.

13. Cosmi, T., Marchesini, E., and Martini, G. 2003. Presence and spread of tospovirus and thrip vectors in Veneto. Inform. Agr. 59:69-72.

14. Derks, A. F. L. M., and Lemmers, M. E. C. 1996. Detection of tospoviruses in bulbous crops and transmissibility by vegetative propagation. Acta Hortic. 432:132-137.

15. Doi, M., Zen., S., Okuda, M., Nakamura, H., Kato, K., and Hanada, K. 2003. Leaf necrosis disease of lisianthus (Eustoma grandiflorum) caused by Iris yellow spot virus. Jpn. J. Phytopathol. 69:181-188

16. du Toit, L. J., Pappu, H. R., Druffel, K. L., and Pelter, G. Q. 2004. Iris yellow spot virus in onion bulb and seed crops in Washington. Plant Dis. 88:222.

17. Gent, D. H., du Toit, L. J., Fichtner, S. F., Mohan, S. K., Pappu, H. R., and Schwartz, H. F. 2006. Iris yellow spot virus: An emerging threat to onion bulb and seed production. Plant Dis. 90:1468-1480

18. Gera, A., Cohen J., Salomon, R., and Raccah, B. 1998. Iris yellow spot tospovirus detected in onion (Allium cepa) in Israel. Plant Dis. 82:127.

19. Gera, A., Kritzman, A., Cohen, J., and Raccah, B. 1998. Tospoviruses infecting bulb crops in Israel. Pages 86-87 in: Recent Progress in Tospovirus and Thrips Research. D. Peters and R. Goldbach, eds. Int. Sympos. Tospoviruses Thrips Floral Vegetable Crops, 4th. Wagengingen, The Netherlands.

20. Hall, J. M., Mohan, K., Knott, E. A., and Moyer, J. W. 1993. Tospoviruses associated with scape blight of onion (Allium cepa) seed crops in Idaho. Plant Dis. 77:952.

21. Hoepting, C. A., Allen, J. K., Vanderkooi, K. D., Hovius, M. Y., Fuchs, M. F., Pappu, H. R., and McDonald, M. R. 2008. First report of Iris yellow spot virus on onion in Canada. Plant Dis. 92:318.

22. Huchette, O., Bellamy, C., Filomenko, R., Pouleau, B., Seddas, S., and Pappu, H. R. 2008. Iris yellow spot virus on shallot and onion in France. Online. Plant Health Progress doi:10.1094/PHP-2008-0610-01-BR.

23. Huchette, O., Filomenko, R., Pouleau, B., Godbert, N., Larièpe, A., Out, H., and Seddas, S. 2006. Development of an easy and reliable method to diagnose the Iris yellow spot virus in Burgundy, France. Page 40 in: Proc. 2006 National Allium Res. Conf., College Station, TX.

24. Jenser, G., and Szenasi, A. 2004. Review of the biology and vector capability of Thrips tabaci Lindeman (Thysanoptera: Thripidae). Acta Phytopathol. Entomol. Hung. 39:137-155.

25. Jones, D. R. 2005. Plant viruses transmitted by thrips. Eur. J. Plant Pathol. 113:119-157.

26. Kritzman, A., Beckelman, H., Alexandrov, S., Cohen, J., Lampel, M., Zeidan, M., Raccah, B., and Gera, A. 2000. Lisianthus leaf necrosis: A new disease of lisianthus caused by Iris yellow spot virus. Plant Dis. 84:1185-1189.
27. Kritzman, A., Lampel, M., Raccah, B., and Gera, A. 2001. Distribution and transmission of Iris yellow spot virus. Plant Dis. 85:838842.

28. Leinhos, G., Müller, J., Heupel, M., and Krauthausen, H. J. 2007. Iris yellow spot virus an Bund- und Speisezwiebeln-erster Nachweis in Deutschland. Nachrichtenbl. Deut. Pflanzenschutzd. 59:310-312. (In German.)

29. Mavrič, I., and Ravnikar, M. 2000. Iris yellow spot tospovirus in Slovenia. Pages 223-225 in: Proc. Congr. Eur. Found. Plant Pathol. 5th. Taormina-Giardini Naxos, Italy.

30. McKenzie, C. L., Cartwright, B., Miller, M. E., and Edelson, J. V. 1993. Injury to onions by Thrips tabaci (Thysanoptera: Thripidae) and its role in the development of purple blotch. Environ. Entomol. 22:1266-1277.

31. Mohan, S. K., and Moyer, J. W. 2004. IYSV symptoms and etiology: Observations since 1989. Page 105 in: Proc. 2004 National Allium Res. Conf. Colorado State University, Fort Collins.

32. Moyer, J. W., Abad, J. A., Ullman, D., and Mohan, K. 2003. INSV and IYSV: The other Tospoviruses in the United States. (Abstr.) Phytopathology 93:S115.

33. Mumford, R. A., Glover, R., Daly, M., Nixon, T., Harju, V., and Skelton, A. 2008. Iris yellow spot virus (IYSV) infecting Lisianthus (Eustoma grandiflorum) in the UK: First finding and detection by real-time PCR. Plant Pathol. 57:768.

34. Nagata, T., Almeida, A. C. L., Resende, R. de O., and de Avila, A. C. 1999. The identification of the vector species of Iris yellow spot tospovirus occurring on onion in Brazil. Plant Dis. 83:399.

35. Nischwitz, C., Pappu, H. R., Mullis, S. W., Sparks, A. N., Langston, D. B., Csinos, A. S., and Gitaitis, R. D. 2007. Phylogenetic analysis of Iris yellow spot virus isolates from onion (Allium cepa) in Georgia (USA) and Peru. J. Phytopathol. 155:531-535.

36. Pappu, H. R., du Toit, L. J., Schwartz, H. F., and Mohan, K. 2006. Sequence diversity of the nucleoprotein gene of Iris yellow spot virus (genus Tospovirus, family Bunyaviridae) isolates from the western region of the United States. Arch. Virol. 151:1015-1023.

37. Pappu, H. R., Hellier, B. C., and Dugan, F. M. 2006. Wild Allium spp. as natural hosts of Iris yellow spot virus. Plant Dis. 90:378.

38. Pappu, H. R., Jones, R. A. C., and Jain, R. K. 2009. Global status of tospovirus epidemics in diverse cropping systems: Successes achieved and challenges ahead. Virus Res. 141:219-236.

39. Pappu, H. R., Rosales, I. M., and Druffel, K. L. 2008. Serological and molecular assays for rapid and sensitive detection of Iris yellow spot virus infection of bulb and seed onion crops. Plant Dis. 92:588-594.

40. Poole, G. J., Pappu, H. R., Davis, R. M., and Turini, T. A. 2007. Increasing outbreaks and impact of Iris yellow spot virus in bulb and seed onion crops in the Imperial and Antelope Valleys of California. Online. Plant Health Progress doi:10.1094/PHP-2007-0508-01-BR.

41. Pozzer, L., Bezerra, I. C., Kormelink, R., Prins, M., Peters, D., Resende, R. de O., and de Ávila, A. C. 1999. Characterization of a tospovirus isolate of Iris yellow spot virus associated with a disease in onion fields in Brazil Plant Dis. 83:345-350.

42. Pozzer, L., Nagata, T., Lima, M. I., Kitajima, E. W., Resende, R. de O., and de Ávila, A. C. 1994. "Sapeca": An onion disease in the SubMédio São Francisco region, Brazil, is caused by a tospovirus with a serologically distinct nucleocapsid protein. Fitopatol. Bras. 19(Suppl.):321

43. Robène-Soustrade, I., Hostachy, B., RouxCuvelier, M., Minatchy, J., Hédont, M., Pallas, R., Couteau, A., Cassam, N., and Wuster, G. 2006. First report of Iris yellow spot virus in onion bulb and seed production fields in Reunion Island. Plant Pathol. 55:288

44. Roggero, P., Masenga, V., and Tavella, L. 2002. Field isolates of Tomato spotted wilt virus overcoming resistance in pepper and their spread to other hosts in Italy. Plant Dis. 86:950-954.

45. Rosales, M., Pappu, H. R., López, L., Mora, R., and Aljaro, A. 2005. Iris yellow spot virus in onion in Chile. Plant Dis. 89:1245.

46. Sampangi, R. K., Mohan, S. K., and Pappu, H R. 2007. Identification of new alternative weed hosts for Iris yellow spot virus in the Pacific Northwest. Plant Dis. 91:1683.

47. Smith, T. N., Jones, R. A. C., and Wylie, S. J. 2006. Genetic diversity of the nucleocapsid gene of Iris yellow spot virus. Australas. Plant Pathol. 35:359-362.

48. Smith, T. N., Wylie, S. J., Coutts, B. A., and Jones, R. A. C. 2006. Localized distribution of Iris yellow spot virus within leeks and its reliable large-scale detection. Plant Dis. 90:729733.

49. Tamura, K., Dudley, J., Nei, M., and Kumar, S. 2007. MEGA4: Molecular Evolutionary Genetics Analysis (MEGA) software version 4.0. Mol. Biol. Evol. 24:1596-1599.

50. Thompson, J. D., Higgins, D. G., and Gibson, T. J. 1994. CLUSTAL W: Improving the sensitivity of progressive multiple sequence alignment through sequence weighting, positionspecific gap penalties and weight matrix choice. Nucleic Acids Res. 22:4673-4680.

51. Uga, H., and Tsuda, S. 2005. A one-step reverse transcription-polymerase chain reaction system for the simultaneous detection and identification of multiple tospovirus infections. Phytopathology 95:166-171.

52. Ward, L. I., Perez-Egusquiza, Z., Fletcher, J. D., Ochoa Corona, F. M., Tang, J. Z., Liefting, L. W., Martin, E. J., Quinn, B. D., Pappu, H. R., and Clover, G. R. G. 2008. First report of Iris yellow spot virus on Allium cepa in New Zealand. Online. New Dis. Rep. 17:Feb. 2008 July 2008. 